\title{
IDENTIFIKASI POTENSI PENGEMBANGAN JALUR PEJALAN KAKI DI KORIDOR JALAN TEGAR BERIMAN, CIBINONG
}

\author{
The Identification of Pedestrian Sidewalk \\ Development Potentials in Tegar Beriman Street Corridor, Cibinong
}

\author{
Firmansyah Bachtiar \\ Program Studi Arsitektur Universitas Tanri Abeng \\ Email : firmansyah.bachtiar@tau.ac.id
}

\begin{abstract}
Abstrak
Rencana pengembangan konsep Cibinong Situ Front City berdampak pada kebutuhan pengembangan infrastruktur penunjang di sekitar lokasi terkait. Jalan Tegar Beriman adalah salah satu koridor utama pintu masuk kawasan pusat pemerintahan Kabupaten Bogor yang termasuk dalam deliniasi pengembangan Situ Front City. Pengembangan kawasan Situ Front City berpotensi menstimulasi peningkatan frekuensi pejalan kaki terutama pada kawasan yang dipengaruhi keberadaan kantor-kantor pemerintahan dan juga potensi wisata di sekitar Situ Kebantenan dan Situ Cikaret. Saat ini, penataan jalur pedestrian sudah dilakukan dari sekitar Kantor Bupati hingga ke Kantor Dinas PUPR Kabupaten Bogor. Penelitian ini difokuskan untuk melihat titik potensi bangkitan pejalan kaki dan ketersediaan ruang pengembangan jalur pejalan kaki pada Ruang Milik Jalan (Rumija) eksisting. Teridentifikasinya potensi dan ketersediaan ruang tersebut akan menjadi pertimbangan dalam prioritas pengembangan segmen jalur pejalan kaki lanjutan disepanjang Koridor Tegar Beriman.
\end{abstract}

Kata kunci: pejalan kaki, ruang milik jalan, cibinong, trotoar

\section{PENDAHULUAN}

Cibinong sebagai ibukota Kabupaten Bogor dikenal sebagai kawasan perkotaan yang memiliki banyak situ alami. Keberadaan situ-situ tersebut saat ini belum dikelola dengan baik sehingga belum memiliki daya tarik untuk menarik wisatawan. Keberadaan situ saat ini lebih pada fungsi alaminya sebagai embung dan penampung air hujan. Konsep situ sebagai bentang alam yang dapat memiliki nilai ekologis dan wisata yang tinggi mulai disadari oleh pemangku kepentingan setempat sehingga muncul rencana pengembangan kawasan pada 3 situ besar yang ada di sekitar kawasan pusat pemerintahan Kabupaten Bogor. Rencana pengembangan ini sudah dituangkan dalam proyek Situ Front City yang mulai direncanakan sejak tahun 2015, dimana pembangunan yang ada akan berbasis memanfaatkan keberadaan embung dan penampungan air hujan (Berita Satu, 2017).

Salah satu bentuk strategi pengembangan dalam Masterplan \& Urban Design Guideline Situ Front City adalah strategi untuk jalur pejalan kaki. Jalur pejalan kaki tepi jalan direncanakan dengan konsep pedestrian sidewalk - dedicated, yaitu jaringan jalur pejalan kaki yang khusus dan 
dipisahkan dengan jaringan jalur sepeda. (Bappedalitbang Kab. Bogor, 2016).

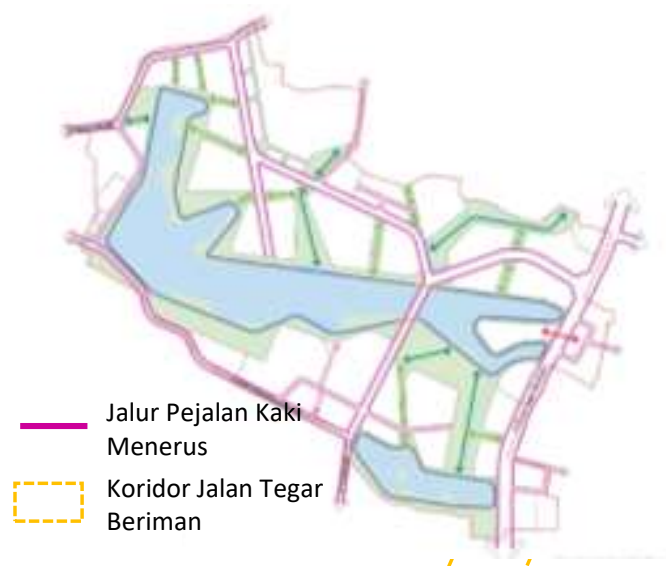

Gambar 1. Rencana Jalur Pejalan Kaki Kawasan Situ Front City.

(Sumber : Bappedalitbang Kab. Bogor, 2016)

Jalur pejalan kaki/pedestrian dalam konteks perkotaan dimaksudkan sebagai ruang khusus untuk pejalan kaki yang berfungsi sebagai sarana pencapaian yang dapat melindungi pejalan kaki dari bahaya yang datang dari kendaraan bermotor (Iswanto, 2006). Pertimbangan perancangan jalur pejalan kaki mencakup keseimbangan interaksi antara pejalan kaki dan kendaraan, faktor keamanan, ruang yang cukup bagi pejalan kaki, fasilitas yang menawarkan kesenangan sepanjang area pejalan kaki dan tersedianya fasilitas publik yang menyatu dan menjadi elemen penunjang. (Shirvani, 1985).

Penataan jalur pejalan kaki di sekitar koridor Tegar Beriman sudah dilaksanakan sejak tahun 2019. Penataan trotoar eksisting dilakukan mulai dari sekitar Masjid Baitul Faizin hingga ke Kantor Dinas PUPR (Tribunews Bogor, 2018). Penataan trotoar tersebut dilakukan melalui perluasan area trotoar eksisting hingga ke arah property line kavling, perbaikan saluran, pemasangan street furniture dan penyediaan ruang untuk vegetasi eksisting.
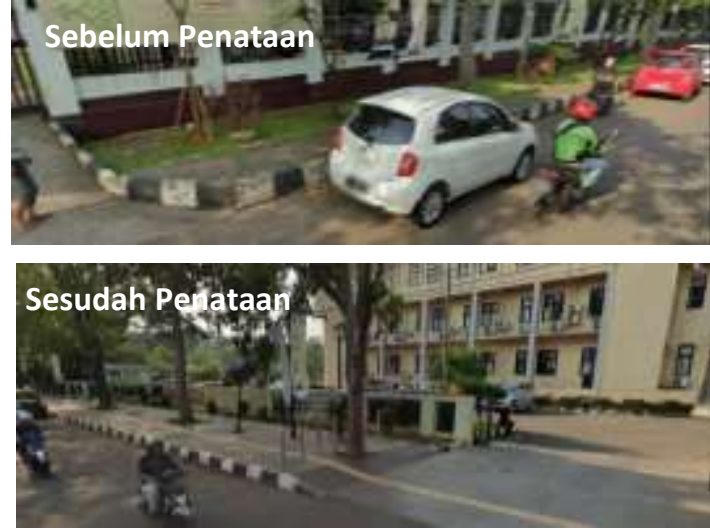

Gambar 2. Penataan Jalur Pejalan Kaki Kantor Bupati-Kantor Dinas PUPR.

(Sumber : Google Streetview, 2019)

Penelitian kali ini bertujuan untuk mengidentifikasi lebih lanjut ketersediaan ruang untuk pengembangan jalur pedestrian menerus di seluruh bagian kordior Jalan Tegar Beriman, serta memetakan bangkitan-bangiktan pejalan kaki yang dapat mendukung pengembangan jalur pedestrian menerus tersebut.

\section{METODE}

Penelitian dilakukan dengan metode kualitatif deskriptif, melalui pengamatan langsung kondisi ruang jalan pada Koridor Tegar Beriman, kecuali pada area yang sudah dilakukan penataan jalur pedestrian.

Untuk memudahkan pengamatan, maka segmen Jalan Tegar Beriman sepanjang 3 $\mathrm{km}$ akan dibagi menjadi beberapa segmen dan sub-segmen pengamatan. Pada setiap bagian pengamatan tersebut dilakukan pengamatan terhadap dua aspek yaitu:

- Ketersediaan ruang pada area ruang milik jalan (rumija) untuk pelebaran jalur pejalan kaki.

- Tipologi ruang antara trotoar eksisting dan batas Ruang Milik Jalan (Rumija).

- Bangkitan pejalan kaki dan keterhubungannya dengan fungsi sekitar. 
Hasil pengamatan kemudian dianalisa melalui mekanisme penilaian dengan skala likert 1-4 dengan penilaian dari sudut pandang peneliti terhadap potensi bangkitan dan juga ketersediaan ruang pengembangan. Kedua aspek tersebut memiliki bobot yang berbeda, dimana potensi bangkitan pergerakan diberikan bobot lebih tinggi $60 \%$ (nilai maksimal=6) sebagai syarat utama prioritas pengembangan jalur pedestrian dan ketersediaan ruang diberi bobot lebih rendah $40 \%$ (nilai maksimal 4). Total skor yang diperoleh pada setiap segmen akan menentukan segmen mana yg menjadi prioritas pengembangan selanjutnya.

\section{PEMBAHASAN}

Penentuan dimensi jalur pejalan kaki antara lain terkait dengan lokasi dan arus pejalan kaki maksimum (Kementerian Pekerjaan Umum dan Peruamahan Rakyat, 2018). Status Jalan Tegar Beriman termasuk dalam kelas jalan arteri sekunder, dengan kategori arus pejalan kaki maksimum 80 pejalan kaki/menit dan dimensi total 5-6 m.

Pada kondisi eksisting, sepanjang Jalan Tegar Beriman sudah ada trotoar dengan lebar rata-rata $1,45 \mathrm{~m}$ dan terbuat dari paving block. Jarak trotoar dengan pagar kavling bervariasi antara $1-4 \mathrm{~m}$. Vegetasi umumnya berupa pohon peneduh yang terletak di bagian dalam sisi trotoar, seringkali berbatasan langsung dengan saluran drainase. Saluran drainase yang ada berupa kombinasi drainase terbuka dan tertutup dengan kondisi yang cukup baik secara umum, meskipun terdapat bagian kawasan yang belum memiliki saluran drainase.

Untuk kemudahan pengamatan pada tapak, maka Jalan Tegar Beriman dibagi dalam 2 segmen yaitu Segmen Utara
(Segmen A) dan Segmen Selatan (Segmen B) dengan total panjang sekitar $3 \mathrm{~km}$ bermula dari Gerbang Tegar Beriman (Cibinong City Mall) hingga ke persimpangan Jalan KRS Dadi Kusmayadi (PDAM).

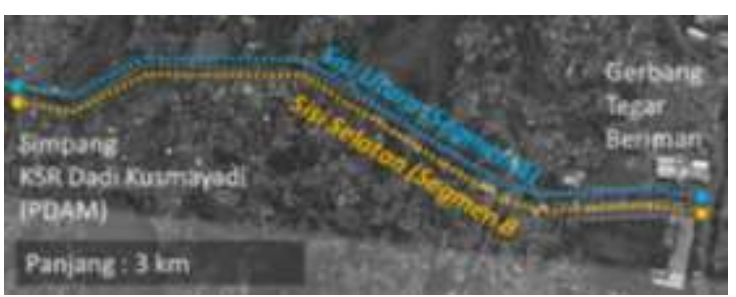

Gambar 3. Pembagian Segmen Jalan Tegar Beriman.

(Sumber : Hasil Analisis, 2020)

Segmen Utara dan Selatan lalu dibagi menjadi 9 sub-segmen dengan dasar pertimbangan antara lain terkait kesesuaian karakter aktivitas, batasan fisik eksisting, dan arahan pengembangan ke depan.

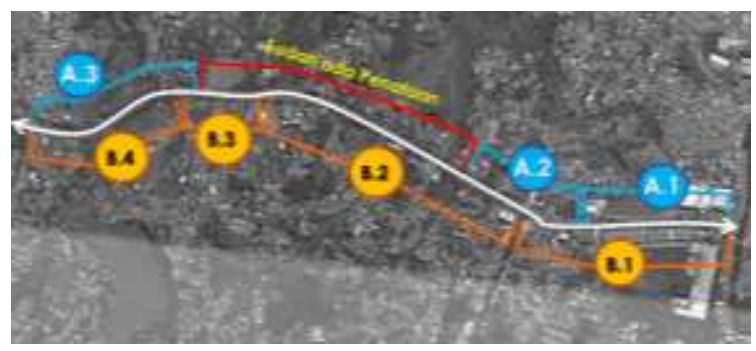

Gambar 4. Pembagian Sub-segmen Jalan Tegar Beriman.

(Sumber : Hasil Analisis, 2020)

Tabel 1. Pembagian Sub-segmen Jalan Tegar Beriman.

\begin{tabular}{|c|c|}
\hline SEGMEN UTARA (A) & $\begin{array}{l}\text { SEGMEN } \\
\text { SELATAN (B) }\end{array}$ \\
\hline $\begin{array}{lr}\text { Segmen } & \text { A.1. } \\
\text { (Gerbang } & \text { Tegar }\end{array}$ & $\begin{array}{lr}\text { Segmen } & \text { B.1. } \\
\text { (Simpang } & \text { Raya }\end{array}$ \\
\hline $\begin{array}{l}\text { Beriman-Masjid Al } \\
\text { Ittihad) }\end{array}$ & Bogor-SPBU) \\
\hline $\begin{array}{l}\text { Segmen A.2. (Kantor } \\
\text { Kecamatan-RM } \\
\text { Kabayan) }\end{array}$ & $\begin{array}{l}\text { Segmen B.2. } \\
\text { (Dispenda-BTSP) }\end{array}$ \\
\hline
\end{tabular}




\begin{tabular}{llll} 
SEGMEN UTARA (A) & \multicolumn{2}{l}{ SEGMEN } \\
& SELATAN (B) & \\
\hline *Segmen Kantor & Segmen & B.3. \\
Dinas PUPR-Kantor & (Bank BJB-Kantor \\
Bupati sudah ada & Polres) & \\
penataan jalur & & \\
pejalan kaki. & & \\
\hline Segmen A.3. (Masjid & Segmen & B.4. \\
Baitul Faizin-Pos & (Kejaksanaan \\
Polisi Simpang & $\begin{array}{l}\text { Negeri- } \\
\text { PDAM) }\end{array}$ & \\
& & McDonalds) & \\
\hline
\end{tabular}

Sumber : Hasil Analisis, 2020

\section{KETERSEDIAAN RUANG PADA RUMIJA}

Pengamatan dilakukan pada sub-segmen melalui identifikasi lebar trotoar eksisting dan jarak yang tersisa antara trotoar eksisting dan batas Rumija untuk pengembangan dan pelebaran jalur pejalan kaki.

Tabel 2. Identifikasi Ketersediaan Ruang Pengembangan Jalur Pejalan Kaki.

\begin{tabular}{|c|c|}
\hline SEGMEN & $\begin{array}{l}\text { KETERSEDIAAN } \\
\text { RUANG }\end{array}$ \\
\hline $\begin{array}{ll}\text { A1 } & \text { Gerbang } \\
\text { Tegar Beriman- } \\
\text { Masjid } & \text { Al Ittihad }\end{array}$ & $\begin{array}{l}\text { - Lebar trotoar } \\
\text { eksisting } 1,45 \mathrm{~m} \\
\text { - Jarak trotoar-batas } \\
\text { rumija : 0,8 - } 2,5 \mathrm{~m} \text {; }\end{array}$ \\
\hline $\begin{array}{l}\text { Segmen A.2. } \\
\text { (Kantor } \\
\text { Kecamatan-RM } \\
\text { Kabayan }\end{array}$ & $\begin{array}{l}\text { - Lebar trotoar } \\
\text { eksisting } 1,45 \mathrm{~m} \\
\text { - Jarak trotoar-batas } \\
\text { rumija : 0,6 - 2,5 m; }\end{array}$ \\
\hline 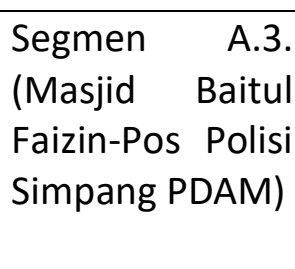 & $\begin{array}{l}\text { - Lebar trotoar } \\
\text { eksisting } 1,45-3 \mathrm{~m} \\
\text { - Jarak trotoar-batas } \\
\text { rumija : 0,6 - 2,5 m; }\end{array}$ \\
\hline $\begin{array}{l}\text { Segmen } \\
\text { (Simpang } \\
\text { Boyaya } \\
\text { Bogor-SPBU) }\end{array}$ & $\begin{array}{l}\text { - Lebar trotoar } \\
\text { eksisting } 1,45 \mathrm{~m}\end{array}$ \\
\hline
\end{tabular}

\begin{tabular}{|c|c|}
\hline SEG & $\begin{array}{l}\text { KETERSEDIAAN } \\
\text { RUANG }\end{array}$ \\
\hline & $\begin{array}{l}\text { - Jarak trotoar-batas } \\
\text { rumija : 0,6 - 1,5 m; }\end{array}$ \\
\hline $\begin{array}{l}\text { Segmen B.2. } \\
\text { (Dispenda-BTSP) }\end{array}$ & 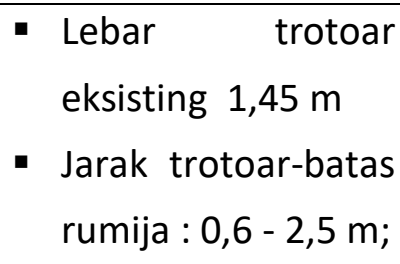 \\
\hline $\begin{array}{l}\text { Segmen } \\
\text { (Bank } \\
\text { Polres) }\end{array}$ & 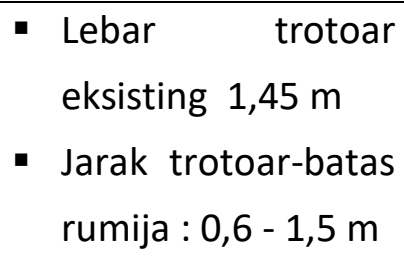 \\
\hline $\begin{array}{l}\text { Segmen B.4. } \\
\text { (Kejaksanaan } \\
\text { Negeri- } \\
\text { McDonalds) }\end{array}$ & $\begin{array}{l}\text { - Lebar trotoar } \\
\text { eksisting } 1,45 \mathrm{~m} \\
\text { - Jarak trotoar-batas } \\
\text { rumija : 0,6 - } 2 \mathrm{~m}\end{array}$ \\
\hline
\end{tabular}

Sumber : Hasil Analisis, 2020

Berdasarkan dari pengamatan terhadap lebar trotoar eksisting dan potensi pengembangan, maka terlihat bahwa ratarata trotoar eksisting yang ada sekarang lebarnya masih dibawah standar ideal. Salah satu standar lebar trotoar yang menjadi acuan yaitu 5-6 m untuk lokasi arteri sekunder (Kementerian Pekerjaan Umum dan Perumahan Rakyat, 2018). Jika dilihat dari standar yang lain, minimal trotoar untuk di pinggir jalan adalah 1,8-3 m (Kementerian Pekerjaan Umum dan Perumahan Rakyat, 2014) atau 1,5 - 1,8 m (ITDP Indonesia, 2019).

Lebar trotoar eksisting yang ada masih di bawah semua standar yang disebutkan di atas. Dari fakta bahwa masih tersisanya ruang berupa jarak trotoar dan Rumija yang bervariasi antara 0,6 m - 2,5 m, maksimum pengembangan jalur pejalan kaki adalah 2,05 - 3,95 $\mathrm{m}$ yang masuk dalam rentang lebar jalur pejalan kaki ideal sesuai standar dari Pedoman Perencanaan, Penyediaan, dan Pemanfaatan Prasarana 
dan Sarana. Jaringan Pejalan Kaki di Kawasan Perkotaan Kementerian PUPR.

\section{TIPOLOGI KETERSEDIAN RUANG SEKITAR TROTOAR EKSISTING}

Berdasarkan pengamatan terhadap lokasi, dapat dilihat tipologi ketersediaan ruang sekitar trotoar eksisting, sebagai berikut:

Tabel 3. Tipologi Ketersediaan Ruang Sekitar Trotoar Eksisting

\begin{tabular}{|l|l|}
\hline \multicolumn{3}{|l|}{$\begin{array}{l}\text { Trotoar berdampingan dengan pelataran } \\
\text { terbuka/plaza }\end{array}$} & $\begin{array}{ll}\text { Pelataran plaza } \\
\text { sebagai ruang } \\
\text { tambahan untuk } \\
\text { pergerakan } \\
\text { pejalan kaki, } \\
\text { memungkinkan } \\
\text { sebagai nodes } \\
\text { untuk kantong } \\
\text { pedestrian. }\end{array}$ \\
\hline
\end{tabular}

Trotoar berdampingan dengan jalur hijau

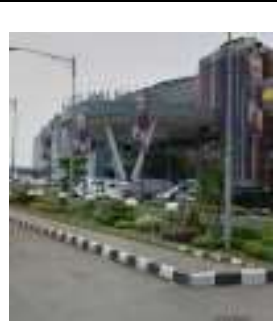

Pelebaran trotoar tidak memungkinkan untuk mengambil sisi jalur hijau karena tehalang tiangtiang reklame dan terkait masalah keselamatan.

Trotoar berdampingan langsung dengan pagar batas lahan kosong

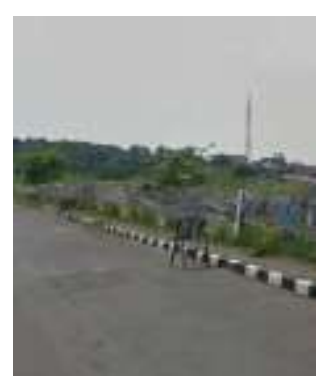

Jika kavling sudah dikembangkan,

ada opsi

pemakaian sebagian area GSB untuk kebutuhan pelebaran jalur pedestrian.

Trotoar berdampingan dengan batas jembatan

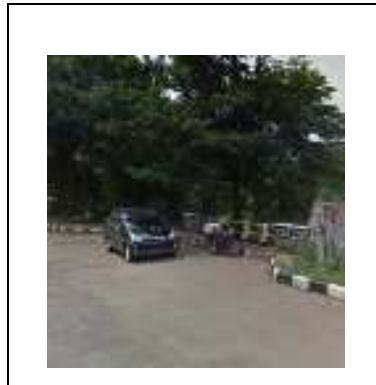

Adanya keterba-
tasan ruang
membuat trotoar
hanya dapat
dikembangkan
memanfaatkan
lebar yang ada saat
ini

Trotoar yang berada di sisi dalam dan dibatasi oleh lansekap dan sisi persil berkontur

\begin{tabular}{|l|l|}
\hline & $\begin{array}{l}\text { Pelebaran jalur } \\
\text { pedestrian dapat } \\
\text { mengambil } \\
\text { sebagian fungsi } \\
\text { jalur hijau tepi } \\
\text { jalan, dengan } \\
\text { tetap } \\
\text { mempertahankan } \\
\text { komposisi } \\
\text { pengaturan jalur } \\
\text { hijau dan trotoar } \\
\text { eksisting }\end{array}$ \\
\hline
\end{tabular}

Trotoar berdampingan dengan ruang terbuka dan pagar

\begin{tabular}{|l|l|}
\hline & $\begin{array}{l}\text { Pelebaran trotoar } \\
\text { ke arah persil } \\
\text { dengan opsi } \\
\text { memanfaatkan } \\
\text { seluruh ruang jalan } \\
\text { untuk kantong } \\
\text { pedestrian dengan } \\
\text { aktivitas khusus, } \\
\text { atau opsi jalur } \\
\text { pejalan kaki } \\
\text { berdampingan } \\
\text { dengan jalur } \\
\text { lansekap. }\end{array}$ \\
\hline
\end{tabular}

Trotoar berdampingan dengan lahan kosong

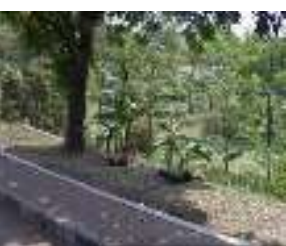

Pelebaran dapat dilakukan sampai ke ruang jalan dengan tidak memberikan batasan fisik ke lahan kosong di 


\begin{tabular}{|l|l|}
\hline & $\begin{array}{l}\text { sampingnya untuk } \\
\text { fleksibilitas akses } \\
\text { saat lahan kosong } \\
\text { nantinya akan } \\
\text { dibangun }\end{array}$ \\
\hline $\begin{array}{l}\text { Trotoar berdampingan dengan properti } \\
\text { privat tanpa pagar }\end{array}$ & $\begin{array}{l}\text { Pelebaran dapat } \\
\text { dilakukan sampai } \\
\text { ke ruang jalan } \\
\text { dengan } \\
\text { memperhatikan } \\
\text { bukaan akses dari } \\
\text { properti yang } \\
\text { berdampingan. }\end{array}$ \\
\hline
\end{tabular}

Sumber : Hasil Analisis, 2020

Berdasarkan tipologi yang dapat dilihat, ada beberapa ruang di sekitar trotoar eksisting yang berpeluang untuk dikembangkan menjadi jalur pejalan kaki yang lebih luas, hingga mencapai hampir 4 m. Pengembangan keseluruhan area Rumija memerlukan penanganan khusus untuk vegetasi eksisting yang ada dan penempatan saluran drainase di bawah jalur pejalan kaki.

\section{BANGKITAN PEJALAN KAKI DAN POTENSI KETERHUBUNGANNYA}

Pengamatan dilakukan pada sub-segmen melalui identifikasi fungsi-fungsi bangunan yang berfungsi sebagai bangkitan pejalan kaki, serta pola keterhubungannya untuk mendorong terjadinya pergerakan pejalan kaki dengan frekuensi rendah-sedangtinggi. Bangkitan pejalan kaki dapat dibagi menjadi Bangkitan Primer, yaitu potensi bangkitan pejalan kaki yang tinggi karena fungsi yang menarik banyak pengunjung (misalnya masjid, mall, kantor dinas). Bangkitan Sekunder adalah potensi bangkitan pejalan kaki yang menengah, maupu potensi adanya keterhubungan fungsi yang memungkinkan orang berjalan kaki (misalnya kantor swasta/non dinas, rumah makan) Berdasarkan hal tersebut, dilakukan pemetaan bangkitan dan potensi frekuensi pergerakan pejalan kaki sebagai berikut:

\section{Segmen A1 (Gerbang Tegar Beriman- Masjid Baitul Faidzin)}

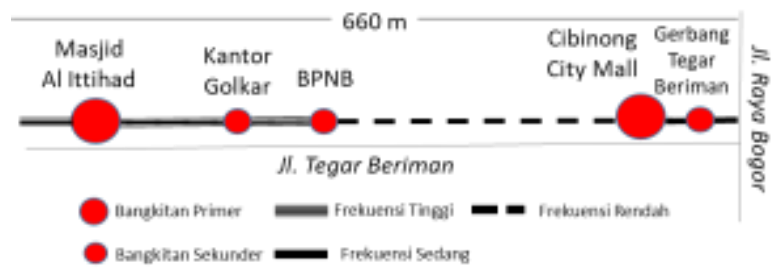

Gambar 5. Bangkitan dan Potensi Pejalan kaki di Segmen A1

(Sumber: Hasil Analisis, 2020)

Bangkitan tinggi berpotensi terjadi di sekitar Masjid Al Ittihad, khususnya saat ibadah sholat Jumat yang akan menarik pengunjung dari kantorkantor sekitar. Frekuensi pejalan kaki juga berpotensi makin besar di sekitar Cibinong City Mall ke arah Jalan Raya Bogor, khususnya untuk menunggu angkutan umum.

2. Segmen A2 (Kantor Kelurahan Pakansari-RM Mang Kabayan)

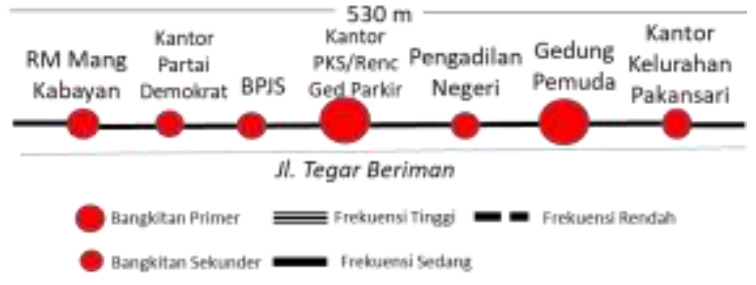

Gambar 6. Bangkitan dan Potensi Pejalan kaki di Segmen A2

(Sumber: Hasil Analisis, 2020)

Bangkitan tinggi berpotensi terjadi di sekitar Gedung Pemuda ketika ada acara kegiatan yang mengundang massa. Rencana pembangunan 
gedung parkir bersama juga akan berpotensi memunculkan pergerakan pejalan kaki. Secara umum, seluruh ruas berpotensi memiki frekuensi pejalan kaki sedang karena adanya potensi berjalan kaki dari kantorkantor dinas yang berdekatan.

3. Segmen A3 (Masjid Baitul Faidzin-Pos Polisi Simpang PDAM)

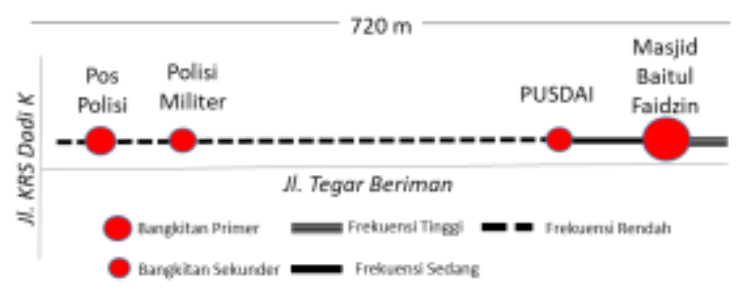

Gambar 7. Bangkitan dan Potensi Pejalan kaki di Segmen A3

(Sumber: Hasil Analisis, 2020)

Bangkitan terbesar pada sub-segmen A3 adalah Masjid Baitul Faidzin yang berada di sisi Kantor Bupati Kabupaten Bogor. Sebagai salah satu masjid terbesar di sekitar Jalan Tegar Beriman, lokasi tersebut akan memiliki frekuensi pejalan kaki yang tinggi pada waktu-waktu ibadah. Antara PUSDAI hingga ke ujung Jalan Tegar Beriman sisi timur, relatif minim potensi pergerakan pejalan kaki karena lebih dominan lahan kosong.

4. Segmen B1 (Gerbang Tegar BerimanSPBU)

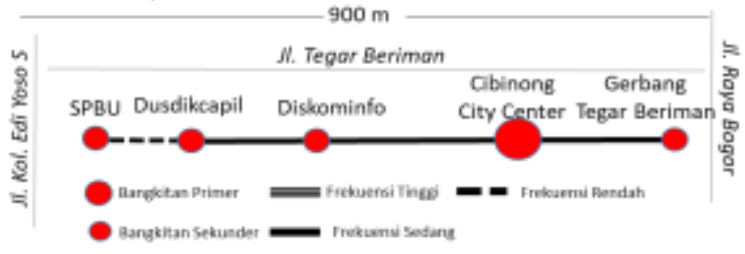

Gambar 8. Bangkitan dan Potensi Pejalan kaki di Segmen B1

(Sumber: Hasil Analisis, 2020)
Cibinong City Center yang banyak memiliki pekerja yang berpotensi menjadi sumber pergerakan pejalan kaki. Arus pergerakan dapat terjadi antara Cibinong City Center ke arah Gerbang Tegar Beriman maupun ke sekitar kantor Dinas ke arah Jalan Kol. Edi Yoso.

\section{Segmen B2 (Dispenda-BPTSP)}

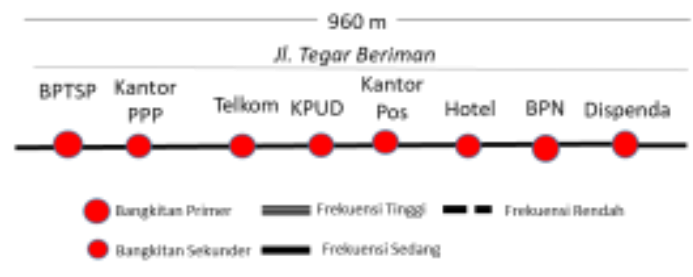

Gambar 9. Bangkitan dan Potensi Pejalan kaki di Segmen B2

(Sumber: Hasil Analisis, 2020)

Pada sub-segmen B2, tidak ada fungsi yang memiliki bangkitan pejalan kaki dominan. Sepanjang segmen 2 lebih banyak terdapat fungsi perkantoran sehingga pergerakan pejalan kaki lebih dimunculkan dari para pekerja di kantor tersebut.

6. Segmen B3 (Bank BJB-Polres)

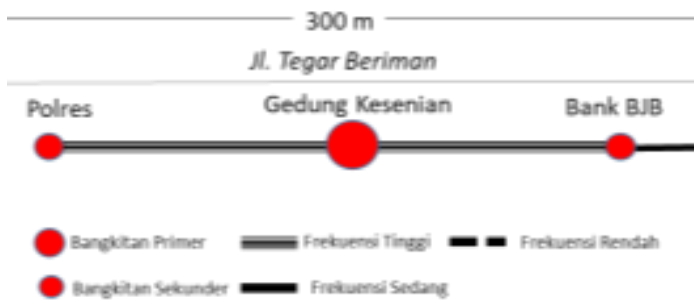

Gambar 10. Bangkitan dan Potensi Pejalan kaki di Segmen B3

(Sumber: Hasil Analisis, 2020)

Bangkitan terbesar pada sub-segmen B3 adalah keberadaan Gedung Kesenian dan Olahraga yang dapat memunculkan massa dalam jumlah 
besar saat ada kegiatan yang berlangsung di dalamnya. Pola pergerakan umumnya akan tinggi bagi para pengunjung yang hendak memakai angkutan umum atau jemputan di sekitar Gedung Kesenian \& Olahraga ke arah Kantor BJB dan Polres.

\section{Segmen B4 (Kejaksaan Negeri- McDonalds)}

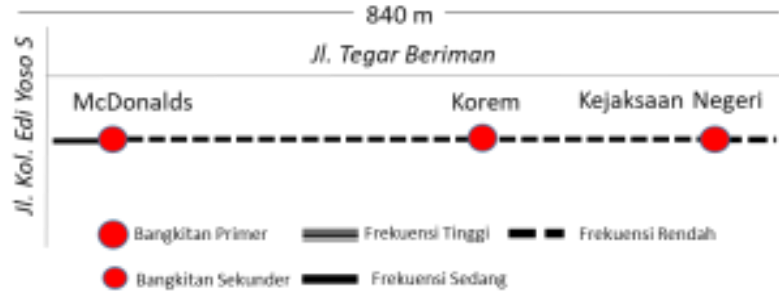

Gambar 11. Bangkitan dan Potensi Pejalan kaki di Segmen B4

(Sumber: Hasil Analisis, 2020)

Sub-segmen B4 tidak memiliki bangkitan pejalan kaki yang dominan, fungsi yang ada di sepanjang subsegmen B4 relatif memiliki intensitas yang rendah. Satu-satunya potensi munculnya pejalan kaki adalah di sekitar McDonalds di persimpangan Jalan Tegar Beriman-Jalan KRS Dadi Kusmayadi.

\section{PENENTUAN PRIORITAS PENGEMBANGAN SUB-SEGMEN}

Penentuan prioritas pengembangan subsegmen akan dilihat dari kondisi ketersediaan ruang dan juga potensi bangkitan yang berkorelasi dengan kebutuhan fasilitasi jalur pejalan kaki yang memadai. Sub-segmen prioritas diarahkan mencakup beberapa segmen yang memiliki keterhubungan agar menghasilkan suatu jaringan jalur pejalan kaki yang menerus. Berdasarkan hal tersebut, maka dilakukan penilaian berdasarkan perhitungan berikut:

Tabel 3. Penilaian Prioritas Pengembangan Jalur Pejalan Kaki pada Sub-segmen

\begin{tabular}{|c|c|c|c|}
\hline $\begin{array}{c}\text { Sub- } \\
\text { segmen }\end{array}$ & $\begin{array}{c}\text { Keterse- } \\
\text { diaan Ruang } \\
\text { (Bobot 60\%; } \\
\text { nilai maks 6) }\end{array}$ & $\begin{array}{c}\text { Bangkitan } \\
\text { Pejalan } \\
\text { Kaki (Bobot } \\
\text { 40\%; nilai } \\
\text { maks 4) }\end{array}$ & $\begin{array}{c}\text { Nilai } \\
\text { Total }\end{array}$ \\
\hline A1 & 4 & 2 & 6 \\
\hline A2 & 4 & 3 & 7 \\
\hline A3 & 4 & 1 & 5 \\
\hline B1 & 2 & 2 & 4 \\
\hline B2 & 4 & 3 & 7 \\
\hline B3 & 2 & 4 & 6 \\
\hline B4 & 3 & 1 & 4 \\
\hline
\end{tabular}

Sumber : Hasil Analisis, 2020

Berdasarkan dari hasil penilaian, yang mempertimbangkan ketersediaan ruang dan juga potensi bangkitan pejalan kaki, maka dapat diperoleh beberapa subsegmen yang dapat dijadikan prioritas penataan. yaitu :

\section{Sub-segmen A1 - A2 (Gerbang Tegar Beriman-RM Mang Kabayan)}

Kedua sub-segmen ini memiliki dua nilai total tertinggi, dan adanya jalur pejalan kaki yang ideal dapat berpotensi untuk menghidupkan aktifitas berjalan kaki, khususnya dengan magnet utama dari Cibinong City Mall. Keterhubungan jalur pejalan kaki dengan beberapa kantor yang ada, dapat memberikan manfaat untuk aksebilitas para pekerja.

\section{Sub-segmen B2 - B3 (Dispenda-Kantor Polres)}

Sub-segmen B2 dan B3 akan sangat dipengaruhi keberadaan kantor-kantor dan juga Gedung Kesenian dan Olahraga yang dapat menjadi simpul pergerakan manusia saat adanya kegiatan di gedung tersebut. Penataan jalur pedestrian 
akan membantu fungsi dan kenyamanan bagi pejalan kaki. Awal segmen di persimpangan Jalan Kolonel Edi Yoso juga dapat menunjang kebutuhan akses dari kawasan Tegar Beriman menuju Stadion Pakansari.

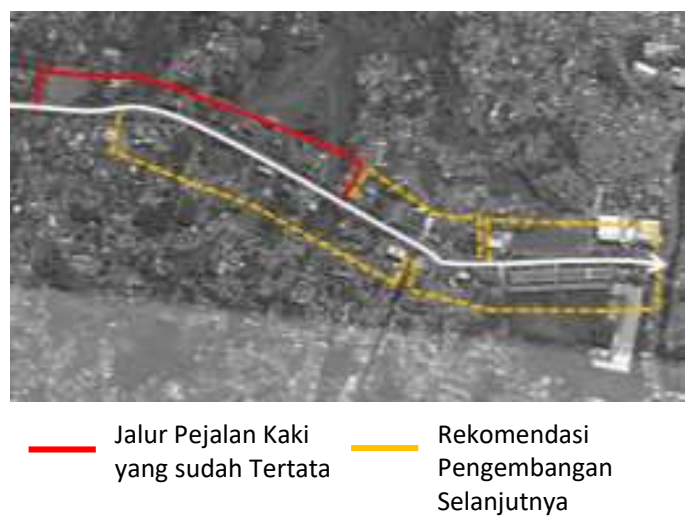

Gambar 12. Prioritas Pengembangan Segmen Jalur Pejalan Kaki (Sumber: Hasil Analisis, 2020)

\section{KESIMPULAN}

Berdasarkan dari analisa yang telah dilakukan, maka dapat terlihat bahwa kondisi trotoar eksisting di Jalan Tegar Beriman saat ini belum sesuai dengan lebar ideal. Pengembangan jalur pejalan kaki masih dimungkinkan dengan memanfaatkan sisa Rumija yang ada, dimana dimungkinkan pelebaran jalur pejalan kaki hingga sekitar $4 \mathrm{~m}$.

Pengembangan jalur pejalan kaki akan dipengaruhi oleh tipologi ruang antara trotoar dan batas Rumija (property line). Pada ruang yang relatif lebar dan berbatasan dengan pelataran terbuka, dapat dikembangkan sebagai nodes untuk kantong pedestrian. Pada area yang berbatasan dengan jalur hijau, dapat dilakukan pengembangan dengan merelokasi area hijau menjadi bagian dari jalur pejalan kaki secara keseluruhan.

Jika dilihat dari seluruh sub-segmen yang ada, maka terdappat dua ruas pengembangan yang dapat diprioritaskan berdasarkan hasil penilaian yang mempertimbangkan aspek ketersediaan ruang dan bangkitan pejalan kaki. Ruas tersebut adalah jalur pejalan kaki di sisi utara mulai dari Gerbang Tegar Beriman/Cibinong City Mall hingga ke RM Mang Kabayan yang berada di sekitar kawasan Situ Plaza Cibinong. Konektivitas ini akan memberikan akses pejalan kaki menerus dari area komersial dan perkantoran yang terhubung dengan area wisata, sehingga dapat memunculkan peningkatan frekuensi pejalan kaki. Segmen berikutnya adalah di sisi selatan, mulai dari Gerbang Tegar Beriman hingga ke Kantor Polres. Konektivitas ini akan memberikan keterhubungan sirkulasi menuju fungsi perkantoran dinas dan juga Gedung Kesenian dan Olahraga.

Keterkaitan dua segmen pengembangan baru yang terkoneksi dengan jalur pejalan kaki yang sudah ditata sebelumnya dari Kantor Bupati sampai ke Kantor Dinas PUPR akan membentuk suatu jaringan jalur pejalan kaki yang melewati fungsi perkantoran, pariwisata, komersial dan pelayanan umum. Kondisi ini diproyeksinkan dampak berdampak positif pada upaya membangkitkan budaya berjalan kaki di masyarakat Cibinong pada uumumnya.

\section{DAFTAR PUSTAKA}

Bappedalitbang Kabupaten Bogor. (2016). Laporan Final Masterplan dan Urban Design Guideline Situ Front City Cibinong. Cibinong: Bappedalitbang Kabupaten Bogor

Fauzy, Naufal. (2018). Akan Dibuat Pedestrian, Trotoar Di Jalan Raya Tegar Beriman Cibinong Dibongkar. https:// 
bogor.tribunnews.com/2018/10/24/akandibuat-pedestrian-trotoar-di-jalan-rayategar-beriman-cibinong-dibongkar. (Diakses 9 Oktober 2020)

Iswanto, Danoe. (2006), Pengaruh Elemenelemen Pelengkap Jalur Pedestrian Terhadap Kenyamanan Pejalan Kaki. Jurnal Ilmiah Perancangan Kota dan Permukiman ENCLOSURE, Volume 5 Nomor 1 . Maret 2006.

ITDP Indonesia. (2019). Panduan Desain Fasilitas Pejalan Kaki: DKI Jakarta 20172022 (Versi 2.0). Jakarta: ITDP Indonesia

Kementerian Pekerjaan Umum. (2014). Peraturan Menteri Pekerjaan Umum Nomo 03/PRT/M/2014 tentang Perencanaan, Penyediaan, dan Pemanfaatan Prasarana dan Sarana Jaringan Pejalan Kaki di Kawasan Perkotaan. Jakarta: Kementerian Pekerjaan Umum.

Kementerian Pekerjaan Umum dan Perumahan Rakyat. (2018). Pedoman Bahan Konstruksi Bangunan dan Rekayasa Sipil. Perencanaan Teknis Pejalan Kaki. Jakarta: Kementerian Pekerjaan Umum dan Perumahan Rakyat.

Saudale, Vento. (2017). Pemkab Bogor Rancang Pengembangan Situ Front City. https://www.beritasatu.com/feri-awan hidayat/megapolitan/440780/pemkabbogor- rancang-pengembangan-situ-frontcity.(Diakses 12 September 2020)

Shirvani, Hamid. (1985). The Urban Design and Process. New York: Van Nostrand Reinhold Company. 